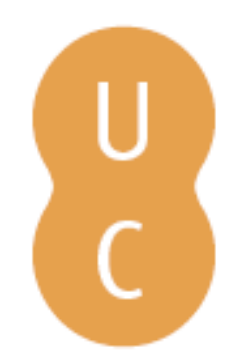

\title{
pompalina
}

\section{Sexual selection and the cultural inheritance of female mating preferences}

Autor(es): $\quad$ Varela, Susana A. M.

Publicado por: Imprensa da Universidade de Coimbra

URL

persistente: URI:http://hdl.handle.net/10316.2/31288

DOI: $\quad$ DOI:http://dx.doi.org/10.14195/978-989-26-0342-1_15

Accessed : $\quad$ 26-Apr-2023 14:28:03

A navegação consulta e descarregamento dos títulos inseridos nas Bibliotecas Digitais UC Digitalis, UC Pombalina e UC Impactum, pressupõem a aceitação plena e sem reservas dos Termos e Condições de Uso destas Bibliotecas Digitais, disponíveis em https://digitalis.uc.pt/pt-pt/termos.

Conforme exposto nos referidos Termos e Condições de Uso, o descarregamento de títulos de acesso restrito requer uma licença válida de autorização devendo o utilizador aceder ao(s) documento(s) a partir de um endereço de IP da instituição detentora da supramencionada licença.

Ao utilizador é apenas permitido o descarregamento para uso pessoal, pelo que o emprego do(s) título(s) descarregado(s) para outro fim, designadamente comercial, carece de autorização do respetivo autor ou editor da obra.

Na medida em que todas as obras da UC Digitalis se encontram protegidas pelo Código do Direito de Autor e Direitos Conexos e demais legislação aplicável, toda a cópia, parcial ou total, deste documento, nos casos em que é legalmente admitida, deverá conter ou fazer-se acompanhar por este aviso.

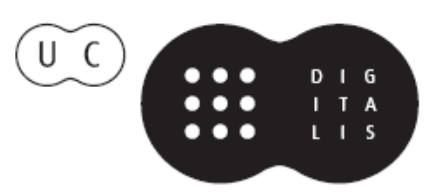


Ana Leonar Pereira João Rui Pita

Pedro Ricarda Fonseca (eds.)
Darwin,

Evalution,

Evolutionisms

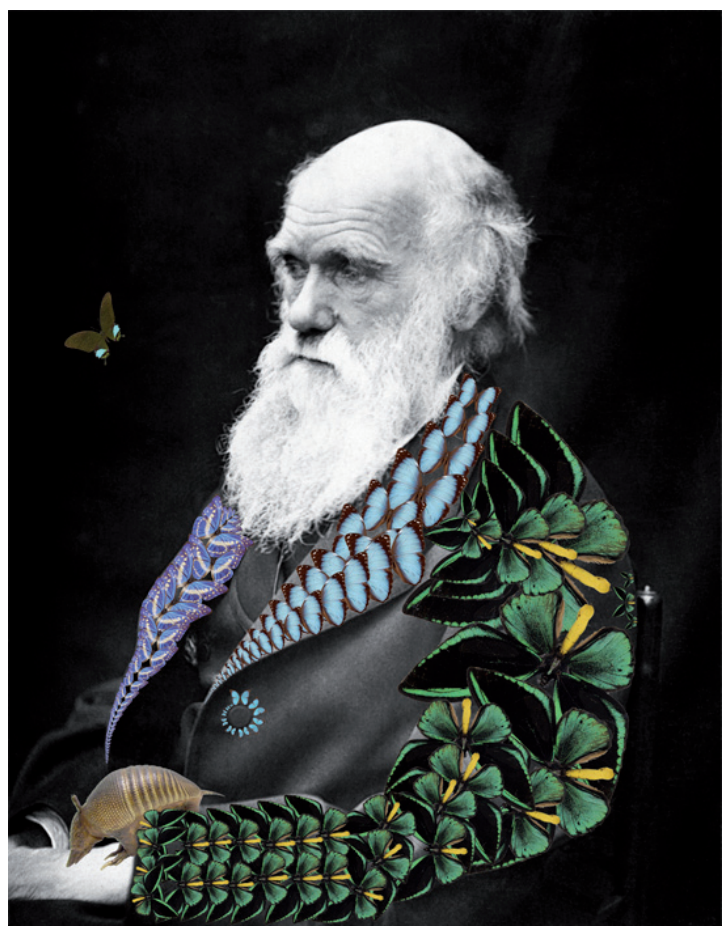


Susana A. M. Varela

Faculdade de Ciências, Departamento de Biologia Vegetal, Centro de Biologia Ambiental, Universidade de Lisboa, Portugal

\section{Sexual selection and the cultural inheritance of FEMALE MATING PREFERENCES}

Since Darwin (1879) hypothesized that female mating decisions may drive sexual selection, that questions like how females gain information about potential mates, and what benefits they receive from choosing particular males as mates, remain key issues in behavioural ecology, and still generate large debate (see reviews in Barnard 2004 and Andersson \& Simmons 2006). Because female preferences for males with particular traits can cause important skews on male reproductive success (Wade $\&$ Pruett-Jones 1990), studying the ecological forces that may affect preference is critical for understanding the diversity of male secondary sexual traits, the differences between the sexes in mating outcomes, the trade-off between multiple matings and survival, the role of sexual conflict in limiting female decisions, and ultimately the evolutionary processes of sexual selection (Barnard 2004).

\section{Independent mate-choice}

Female mating preferences can be variable between and within populations, and explanations for this variation usually assume that preferences remain fixed throughout the lifetime of the organism and result from strong genetic influences (e.g. Kirkpatrick \& Ryan 1991; Barnard 2004; Andersson \& Simmons 2006). Fisher (1930) was the first to formalize such a genetically based hypothesis by means of a theoretical model, in which he assumes that females find the phenotypic characteristics of certain males attractive, and that both male characteristics and female preferences are genetically heritable. Due to skewed reproductive success towards the most attractive males, both attractive traits and the preference for them spread through the population, leading to the evolution of traits more and more exaggerated over generations. Ultimately, however, this runaway process will be stopped by natural selection, as trait size reached the point where its reproductive advantage is outweighed by its survival (Barnard 2004).

Several experimental studies were able to provide evidence for the covariance between male traits and female preferences, as predicted by Fisher's runaway model (reviewed in Barnard 2004). However, the debate still persists on the kind of underlying mechanism that may be at the origin of such a co-evolutionary response. (1) According to Fisher (1930), females prefer males with certain phenotypic traits due to a genetic predisposition in preference that is acquired by chance. Alternative hypotheses, however, 
suggest that (2) female genetic preferences are not arbitrarily acquired, but that they are an evolutionary response to genetic indicator cues on the utilitarian benefits (good genes) that a male can provide to the female as a mate (Barnard 2004; Andersson \& Simmons 2006). Genetic indicators of quality are based on correlations between a sexually selected trait and the phenotypic condition of its possessor. Since those traits are costly to the males, only robust individuals in good condition can afford to develop them (the handicap principle, Zahavi \& Zahavi 1997). (3) Female preferences may also involve phenotypic traits that reflect the ability of the male to provide non-genetic advantages that would increase the survivorship and reproductive potential of his offspring, such as a high-quality territory, increased fecundity from nuptial food gifts, protection and parental care (Barnard 2004). Finally, (4) the preference of females for a particular male ornament can simply result from a female sensory bias if that kind of preference had initially been selected for other reasons, but that do not confer at present any reproductive advantage (Barnard 2004). There is considerable empirical support for all these mechanisms, and since they are not mutually exclusive and most probably co-occur, the challenge is to learn how to distinguish between them and to estimate their relative importance for the evolution of female mating preferences and male attractive traits (reviewed in Andersson \& Simmons 2006).

\section{Non-independent mate-choice}

Another important factor that might equally affect the evolutionary dynamics of sexual selection, and that has been largely ignored until recently, is that femalemating preferences may not always be independent, and therefore not fixed. Because Darwin didn't know about the existence of genes, he described sexual selection as «the habitual or even occasional preference by the female of the more attractive males», and that such preference, although not fixed, "would almost certainly lead to their modification; and such modifications might, in the course of time, be augmented to almost any extent, compatible with the existence of the species» (Darwin 1879, cap. 14). Our present knowledge about genes and genetics has allowed us to better understand the evolutionary process in its whole. However, it is a mistake to ignore the influence of non-genetic mechanisms on sexual selection. In fact, genetically inherited information may not be enough to assess male heterogeneity in quality. As a complement to females' genetic predisposition for males with particular traits, mating decisions may be influenced by the choices of other females, that is to say, by the social information that is provided inadvertently by the mating decisions of conspecific-model females (Nordell \& Valone 1998; Valone \& Templeron 2002; Wagner \& Danchin 2003; Danchin et al. 2004; Danchin \& Wagner 2008).

The use of inadvertent social information (generally known as public information) may, indeed, be a more parsimonious and reliable approach to the mate-choice process (Danchin et al. 2004). Because it is extracted from the direct observation of the success and failure of conspecifics engaged in the efficient performance of their mating activities, it thus reflects conspecifics' genotypic dissimilarity in quality, providing reliable information on with whom to mate. It could have therefore evolved as a direct adaptation to assess more effectively the quality of potential mates. Furthermore, 
because it integrates, in a unique observation, the various qualities required in a mate, it reduces the time and energy invested on independent trial-error attempts (Brooks 1998; Nordell \& Valone 1998; Valone \& Templeton 2002; Danchin et al. 2004).

One consequence of using public information to decide with whom to mate is the copying of successful conspecific choices by multiple individuals attempting to benefit from the same favourable mating conditions (Wagner \& Danchin 2003). Mate-choice copying occurs if the mating preference of a (observing) female for a particular (target) male increases or decreases, depending on whether that male mated previously or was avoided by other (model) females (Pruett-Jones 1992). Prospecting females should be observed copying other females only when their discriminating ability is inadequate (Nordell \& Valone 1998). When this is not the case, females should rely first on their own experience to efficiently assess male quality (e.g. Gibson \& Höglund 1992; Brooks 1998; Nordell \& Valone 1998). When females lack the ability to discriminate between two males of different quality, observing the choices of more experienced females should allow them to mate with the best male (Nordell \& Valone 1998; Wagner \& Danchin 2003). Finally, observing females will choose mates entirely on the basis of true copying only if they are directly exposed to the mating interactions of model females, which is the only way of obtaining direct information about male attractiveness or quality (Danchin et al. 2004).

The first comprehensive series of laboratory studies about social influences on mate choice are that of Dugatkin \& Godin (1992), using guppies (Poecilia reticulata) as subjects, and that of Galef \& White (1998), using japanese quails (Coturnix japonica). Taken together, the results of both these studies provide strong evidence that the attractiveness of a previously non-preferred male to an observing female is markedly increased after she sees him mating. Several other empirical, theoretical and experimental studies in a variety of vertebrate groups (see reviews on Galef \& White 2000, Danchin et al. 2004, and Valone \& Templeton 2002), have been providing evidence that animals actually use public information to chose their mates. More recently, my co-authors and I (Mery \& Varela et al. 2009) have analysed, in Drosophila melanogaster, if the mating preferences of an observing female for males of contrasting phenotypes (developmentally stressed versus unstressed) increased or decreased, depending on whether the males mated previously or were avoided by other (model) female. In the same way as with the other experiments, prospector females increased their preference for the previously non-preferred male (the stressed one), by increasing the time they spent near him. This is the first study providing evidence of mate-choice copying in an invertebrate species, suggesting that such a strategy is probably widespread in nature.

\section{The cultural inheritance of female mating preferences}

When placed on the general framework of animal communication and learning, conspecific copying may lead to the transmission of behavioural patterns among individuals in a process that may be similar to the cultural transmission of traditions in humans (Danchin et al. 2004; Laland \& Janik 2006; Danchin \& Wagner 2008). However, for copying to result in the cultural inheritance of mating preferences, individual females 
must not only copy the mate choice decisions of other females, but they should also tend to repeat this type of behaviour by generalizing their socially induced preference for a particular male to other males that share his distinctive characteristics (Brooks 1998). Such social generalization of female mating preferences has been described in some mammal (e.g. Whiten et al. 1999), bird (e.g. White and Galef 2000b) and fish species (e.g. Dugatkin et al. 2002; Godin et al. 2005).

For instance, White \& Galef (2000b), in an additional set of experiments with japanese quails, allowed focal females to see an artificially coloured male (with red or blue colour patches in their chest feathers), or a pseudo-mutant male (with three albino feathers glued to its crown) either mating with a model female or standing alone. In a second step, each focal female was allowed to chose between two new males, one red and the other blue, or one a pseudo-mutant and the other a normal-looking male (with three normal feathers glued to its crown). In both experiments, the authors found that those focal females that had seen a red, blue or pseudo-mutant male mate with a model female were more likely to mate with another red, blue or pseudo-mutant male, than were those focal females that had seen an empty cage or a red, blue or pseudo-mutant male standing alone in the cage.

Dugatkin et al. (2002) and Godin et al. (2005), in their experiments with guppies, found that individual females not only copy the observed mating preferences of other females for initially non-preferred less coloured males (Dugatkin 1998), but also that (1) an initial act of mate-choice copying had affected the mating preferences of significantly more observer females, tested consecutively in a series (Dugatkin et al. 2002); and that after copying (2) individual female guppies were significantly more likely than expected by chance to generalize their copied preference for the same male phenotype when presented with different males one day later (Godin et al. 2005).

In our experiments with fruit flies (Mery \& Varela et al. 2009), we have likewise manipulated male attractiveness by showing an observing female a sequence of males of two artificially coloured types, with one type being accepted and the other rejected for copulation. Prospector females preferably mated with the colour type of the males they had previously observed copulating over males of the rejected type, suggesting that female Drosophila can also generalise socially learned information.

The ability shown in vertebrates to generalise from individuals to categories indicates a sophisticated level of cognition that can expedite the transmission of female preferences to other individuals (Danchin \& Wagner 2008), and therefore accelerate the spread of novel male traits through a population (White \& Galef $2000 b$; Godin et al. 2005), even if there is no inherent genetic preference for those traits (Agrawal 2001). Evidence that mate-choice copying and social generalisation also exist in invertebrates (Mery \& Varela et al. 2009) greatly expands the potential of these processes to affect the evolution of female mating decisions, to induce socially biased mate choice, and thus to increase the opportunity for sexual selection to occur (Wade \& Pruett-Jones 1990; Pruett-Jones 1992; Galef \& White 2000; Mery \& Varela et al. 2009).

However, understanding to what extent such a cultural mechanism of mate choice (1) can consistently modify selection pressures for certain male traits, (2) induce reproductive isolation between populations with different cultural traditions, and, ultimately, (3) favour the emergence of new species, are questions that are only now being proposed, meaning that future studies on these issues should be promising. 


\section{References}

AGRAWAL A.F. 2001. The evolutionary consequences of mate copying on male traits. Behavioral Ecology and Sociobiology 51:33-40.

ANDERSSON M. \& SIMMONS L.W. 2006. Sexual selection and mate choice. Trends in Ecology \& Evolution 21: 296-302.

BARNARD C.J. 2004. Animal behaviour. Mechanism, development, function and evolution. Pearson Education Ltd, Harlow.

BROOKS R. 1998. The importance of mate copying and cultural inheritance of mating preferences. Trends in Ecology \& Evolution 13: 45-46.

DANCHIN É., GIRALDEAU L.A., VALONE T.J. \& WAGNER R.H. 2004. Public information: from nosy neighbors to cultural evolution. Science 305: pp. 487-491.

DANCHIN, É. \& WAGNER, R. H. 2008. Cultural Evolution. In Behavioural Ecology, eds. Danchin, É., Giraldeau, L.-A. \& Cézilly, F., pp. 693-726, Oxford University Press, Oxford.

DARWIN C.R. 1879. The Descent of Man and Selection in Relation to Sex. John Murray, $2^{\text {nd }}$ edition. London.

DUGATKIN L.A. 1998. Genes, copying, and female mate choice: shifting thresholds. Behavioral Ecology 9: 323-327.

DUGATKIN L.A. \& GODIN J.G.J. 1992. Reversal of female mate choice by copying in the guppy (Poecilia reticulata). Proceedings of the Royal Society of London Series B-Biological Sciences 249: 179-184.

DUGATKIN L.A., LUCAS J.S. \& GODIN J.G.J. 2002. Serial effects of mate-choice copying in the guppy (Poecilia reticulata). Ethology Ecology \& Evolution 14: 45-52.

FISHER R.A. 1930. The genetical theory of natural selection. Clarendon Press, Oxford.

GALEF B.G Jr. \& WHITE D.J. 1998. Mate-choice copying in japanese quail, Coturnix coturnix japonica. Animal Behaviour 55: 545-552.

GALEF B.G Jr. \& WHITE D.J. 2000. Evidence of social effects on mate choice in vertebrates. Behavioural Processes 51: 167-175.

GIBSON R.M. \& HÖGLUND J. 1992. Copying and sexual selection. Trends in Ecology \& Evolution 7: 229-232.

GODIN J.G.J., HERDMAN E.J.E. \& DUGATKIN L.A. 2005. Social influences on female mate choice in the guppy, Poecilia reticulata: generalized and repeatable trait-copying behaviour. Animal Behaviour 69: 999-1005.

KIRKPATRICK M. \& RYAN M.J. 1991. The evolution of mating preferences and the paradox of the lek. Nature 350: 33-38.

LALAND K.N. \& JANIK V.M. 2006. The animal cultures debate. Trends in Ecology \& Evolution 21: 542-547.

MÉRY F. ${ }^{1}$, VARELA S.A.M. ${ }^{1}$, Danchin É., Blanchet S., Parejo D., Coolen I. \& Wagner R.H. 2009. Public versus personal information for mate copying in an invertebrate. Current Biology 19 (9):730-4. ${ }^{1}$ These authors contributed equally to this work.

NORDELL S.E. \& VALONE T.J. 1998. Mate choice copying as public information. Ecology Letters 1: 74-76.

PRUETT-JONES S. 1992. Independent versus non-independent mate choice: do females copy each other? American Naturalist 140: 1000-1009.

VALONE T.J. \& TEMPLETON J.J. 2002. Public information for the assessment of quality: a widespread social phenomenon. Philosophical Transactions of the Royal Society Series B-Biological Sciences 357: 1549-1557.

WADE M.J., PRUETT-JONES S.G., 1990. Female copying increases the variance in male mating success. Proceedings of the National Academy of Sciences of the USA 87: 5749-5753. 
WAGNER R.H. \& DANCHIN É. 2003. Conspecific copying: a general mechanism of social aggregation. Animal Behaviour 65: 405-408.

WHITE D.J. \& GALEF B.G. 2000b. "Culture" in quail: social influences on mate choices of female Coturnix japonica. Animal Behaviour 59: 975-979.

WHITEN A. et al. 1999. Cultures in chimpanzees. Nature 399: 682-685

ZAHAVI A. \& ZAHAVI A. 1997. The Handicap Principle. Oxford University Press, Oxford. 